\title{
Analysis of the Cinapel Bridge's Construction Operations using Simulation
}

\author{
Muhamad Abduh $^{1}$, Siska Halvireski ${ }^{2}$, Catherine Delfani ${ }^{2}$, Ryobi Irfanto ${ }^{2}$, Reini D. Wirahadikusumah ${ }^{1}$ \\ Associate Professor, Faculty of Civil and Environmental Engineering, Institute Technology of Bandung, Indonesia \\ Graduate Student, Faculty of Civil and Environmental Engineering, Institute Technology of Bandung, Indonesia ${ }^{2}$
}

\begin{abstract}
Simulation has been well known as an effective technique that enables planning and analysis of a construction operation to be performed in advance anticipating problems of efficiencies that would occur in the implementation phase. Therefore, simulation technique could be used to design resources associated with a construction operation to be optimal and to analyze an ongoing operation to be evaluated and refined. This paper discusses the use of simulation to analyze several construction operations, i.e., bored piles, pile caps, piers, and girders, that will be used in building the Cinapel's Bridge at the Cisumdawu Toll Road Project. The simulation using WebCYCLONE was utilized to determine the most optimal resources needed in each construction operation; resources needed to gain the highest productivity and the lowest wastes. Data of each operation for simulation were gathered from the field, as well as opinions from the practitioners related to the project. The results of the simulation are presented and recommendations are made for the contractor to refine the on-going construction operations as well as to design construction operations before the implementation in the fields.
\end{abstract}

Keywords—Bridge Construction Method, Construction Operation, Productivity, Simulation, Waste

\section{INTRODUCTION}

The demand for infrastructure development in Indonesia is increasing as the needs to support the community's growth is inevitably. Toll road is one of the infrastructures that is currently being intensively built in Indonesia, especially in Java island. In year 2015 until year 2019, the government planned to build more than $1,500 \mathrm{~km}$ of new toll road all over Indonesia [1].

The Cisumdawu Toll Road project is one strategic toll road project in Indonesia since this toll road becomes a continuation of the Java toll road plan that links the Cikampek-Palimanan toll road with the PadalarangCileunyi toll road, and then will connect two big cities in West Java Province, i.e., Bandung and Cirebon. In this project, there is a bridge, called Cinapel Bridge, which is very important structure lied in the alignment of the toll road and considered as critical construction. It has total length of 430 meters, consisting of ten 43 -meter spans, and the highest altitude from the ground is about 30 meters. The soil underground is categorized into very hard soil with N-SPT more than 50 and consists of boulders.

On the other hand, a construction operation is demanded to be more effective and efficient in using resources with the aim to maximize the productivity of the construction operation itself. One way to reach that goal is to simulate the construction operation during the planning phase. The CYCLONE (Cyclic Operations Network) modeling technique is widely used for the simulation purpose because of its adaptability to cyclic construction operations, and because it is a convenient system to use [2]. The CYCLONE modeling emphasizes the logical sequence of construction activities and the effect of their interaction on productivity. For simulation purposes, the WebCYCLONE is a special purpose simulation software that could measure construction operation productivity with only require programming code based on construction operation based on the CYCLONE model [3].

This paper discusses the use of simulation to analyze construction operations involved, such as bored pile, pile caps, pier, and girder, in the construction of the Cinapel bridge that lies in the alignment of the Cisumdawu Toll Road project. However, the focus of this paper is only in the operation of girder erection with lifter method. Since the major constraint that was faced by the project is the land acquisition in the bridge's approaches, the method for girder erection is done from below and side of the bridge using a lifter.

The main purpose of the study was to design the PCI girder erection using lifter method in the Cinapel Bridge. The design of construction operation of the PCI girder erection was done using the CYCLONE modeling technique and the simulation was performed using the WebCYCLONE software that is available online. The simulation will provide optimum lifter method, combination of resources, idleness of resources, and duration of the construction. A sensitivity analysis was used to provide the combination of resources that will produce the optimal operation.

\section{METHOD}

The study was conducted as follow: 
1. Literature review of PCI girder construction methods, especially the lifter method.

2. Data collection from Cisumdawu Toll Road project by interviews and field data acquisition of the work tasks that were already performed.

3. Modeling the PCI girder erection using CYCLONE as depicted in Tables 1 and 2 .

4. Translating the model into input file for simulation on the WebCYCLONE site as shown in Table 3.

5. Sensitivity analysis of the PCI girder erection for the Cinapel bridge by lifter method to determine the optimal resources.

As a modeling techniques of a system, the most important step in simulation is the modeling of a process or system that will be studied. The model should be accurately representing the real system or process. However, the simplification and assumptions are always made that disregard some minor aspects of the real system or process.

There are three strategies in modeling a construction operation for simulation:

1. Event start; the simulation is based on a scheduled event, it executes one event and then moves on to another event.

2. Process interaction; a simulation in terms of transactions that occur in a process associated with the resource.

3. Activity scanning; a simulation is viewed from activities in a system.

In CYCLONE modeling technique, there are several elements used to describe a construction operation. Tables 1 and 2 are showing the elements that used in CYCLONE modeling.

Table 1. Modeling Elements [2]

\begin{tabular}{cl}
\hline Name & \multicolumn{1}{c}{ Fymbolion } \\
\hline Normal Activity & $\begin{array}{l}\text { Units ariving at normal will be processed right } \\
\text { away without delaying } \\
\text { Units ariving at COMBI will be processed if } \\
\text { units are available in all proceceding Queue } \\
\text { node. }\end{array}$ \\
Queue node & $\begin{array}{l}\text { Queue provides position that allows units are } \\
\text { delayed pending COMBI activities. } \\
\text { Consolidate function node performs the } \\
\text { consolidate }\end{array}$ \\
Anction node & $\begin{array}{l}\text { Counter measures the modeled system's } \\
\text { production rate. } \\
\text { Arcs show the logic that units flows from } \\
\text { element to element }\end{array}$ \\
\hline
\end{tabular}

Table 2. Possibility of element A precedes element B [2]

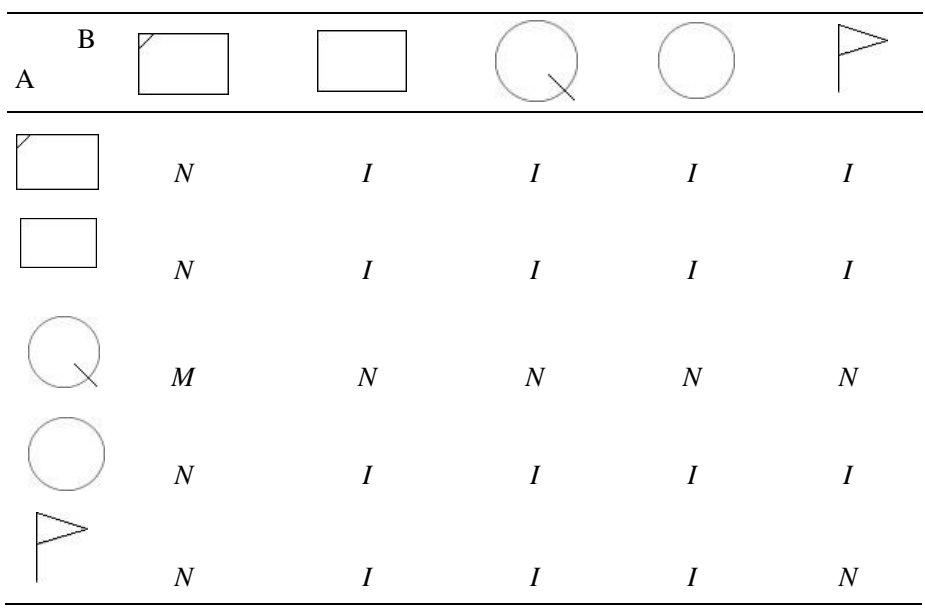

Note:

$\mathrm{M}=$ must; $\mathrm{I}=$ allowed; $\mathrm{N}$ = not allowed 
Table 3. Formats Used in WebCYCLONE Simulation Coding [3]

\begin{tabular}{|c|c|}
\hline Name & General Format \\
\hline Normal Activity & 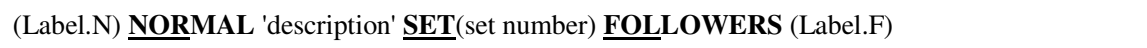 \\
\hline Combination (COMBI) activity & 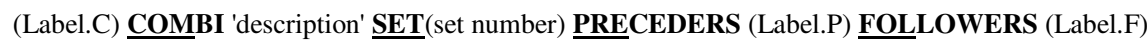 \\
\hline Queue node & 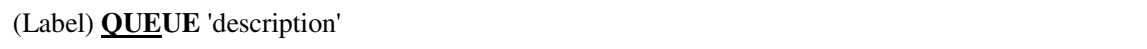 \\
\hline Consolidate function node & (Label.N) QUEUE 'description' GENERATE (number to be generated) \\
\hline Counter & 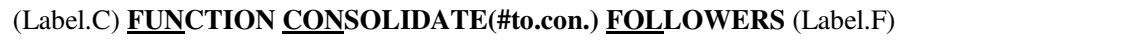 \\
\hline Arc & (Label.C) FUNCTION COUNTER FOLLOWERS (Label.F) QUANTITY (quantity) \\
\hline
\end{tabular}

The WebCYCLONE is a web-based special purpose simulation software available online. The input of WebCYCLONE is built by special syntaxes with certain format as depicted in Table 3. The output of the software includes productivity value, idleness of resources, and cost related to the modeled construction operation.

The sensitivity analysis was conducted to determine the effect of changes in production parameters on changes in production system performance. By conducting sensitivity analysis, the possible consequences of these changes can be identified and anticipated beforehand. After conducting the analysis, it can determine the impact of the change that will affect the feasibility of the project.

Only secondary data were collected for this study. The primary data cannot be collected since the installation work has not been implemented yet as of the study was conducted. The secondary data is obtained from various literature and sources to estimate the duration of the work tasks of the girder erection from previous projects and some adjustments made to be implemented in the Cinapel Bridge project.

\section{MODELING THE CONSTRUCTION OPERATIONS}

The construction of the Cinapel bridge consists of several construction operations as depicted in Figure 1. However, in this study, only girder erection operation that is investigated.

PC-I (pre-stressed concrete I-type) girder is used in the Cinapel Bridge. The production of the PC I girder could be done on-site or off-site. The girder then transported to the site using a low-bed truck. While the erection to the location is done using a lifter. The whole erection processes are depicted in Figure 2.

For the erection purpose, the operation involves several resources to perform some work tasks. The length of the PC-I girder is 42 meters, with a height of 2 meters, and a weight of 80 tons. The PC-I girder is designed to accept only vertical loads and not to receive horizontal loads. This causes the process of transporting the PC I girder from the storage location (stockyard) to the installation location should be made as flat as and as straight as possible. This is to avoid the occurrence of horizontal force due to excessive trailer movement that can cause girder beam to snap.

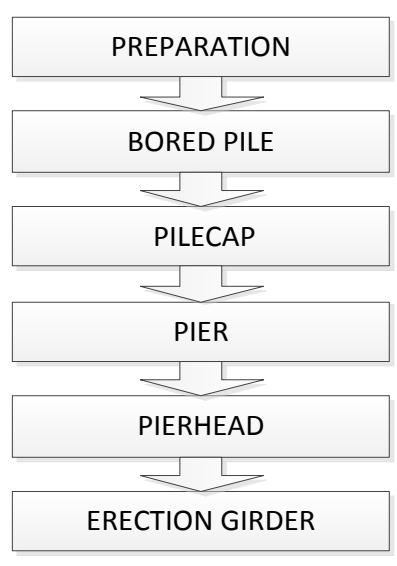

Figure 1. Flowchart of Bridge Works

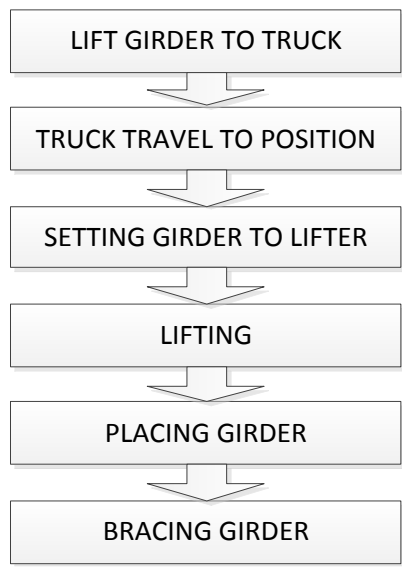

Figure 2. Flowchart of Erection of the PC I Girder

The girder transportation begins with lifting the girder using two cranes and then placing the girder on the truck. The girder is then transported by truck to the location of designated piers. The erection of the girder from the truck to the pier head is done using a lifter supported by an erection team.

For modeling the erection of PC-I girder using the CYCLONE modeling techniques, the resources and work tasks associated with the operations were identified as follow: 
Resources:

1. Two cranes

2. Two spotters

3. One lifter

4. One truck

5. One erection team

Work tasks:

1. Lifting PC I girder to truck

2. Truck travels to site

3. Truck back to yard

4. Placing girder to position

5. Lifting PC I girder

6. Lifter moves to position

7. Placing PC I girder

8. Bracing Girder

Based on the resources and work tasks identified, the cycle of each resource or unit flow, as well as the cycle of the operation could be developed as the integration of all cycles of resources. After the integration of the unit flow's cycle, the initialization of each resource is determined so that the operation of PC I girder erection could begin to be simulated. The final CYCLONE model of this operation is depicted in Figure 3.

The explanation of CYCLONE model in Figure 3 is as follow:

1. The first work task is lifting the girder located in the stockyard onto the truck. The resources needed in this work task are two cranes and one truck. Both cranes and the truck must be available together so the work can be performed.
2. The truck then transports the girder to the location for erection.

3. The next work task is positioning the girder to the designated location near the piers and setting the girder to the lifter. The resources needed are two cranes to transport girder to the lifter's location, and a spotter to set girder placement on the lifter.

4. The truck then returns to the stockyard to pick-up another girder.

5. The next work task is to lift the girder to the pier head using the lifter. The resources needed are the operator who operates the lifter and a spotter who determines the placement of the girder.

6. After the girder is successfully lifted, the girder is shifted to the designated location and then placed on the bearing pad.

7. Installation of girder on the bearing pad requires an erection team consisting of 16 people. After girder installation, the girder was braced by welding the PC-I girder to the pier head or with another girder next to it; to prevent PC-I girder overturned.

8. When the task was finished, the lifter will return to its original position.

9. The operation productivity is calculated when 1 girder has been successfully installed.

Based on a literature of previous project [4], the durations of all work tasks were determined as in Table 4. It can be noticed that the three-estimate method was used in for determining the work tasks durations probability density function (PDF).

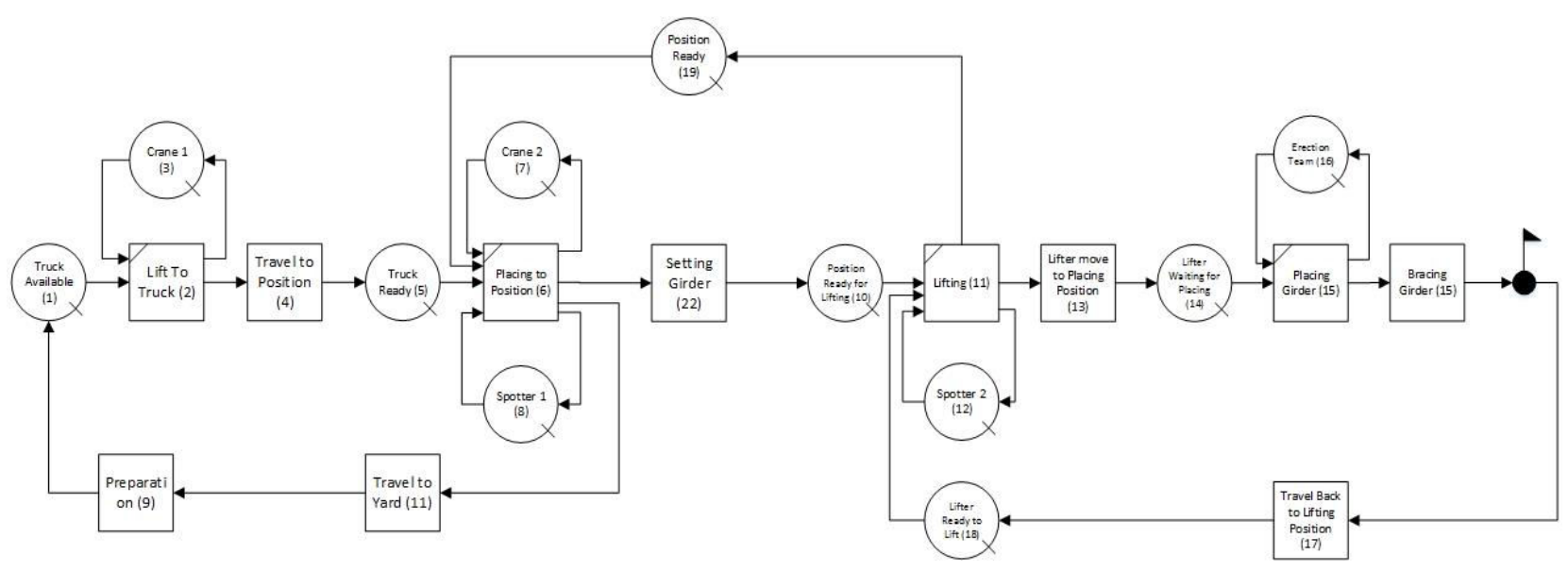

Figure 3. CYCLONE Model of the Erection PC-I Girder Using Lifter 
The Third International Conference on Civil Engineering Research (ICCER)

August $1^{\text {st }}-2^{\text {nd }}$ 2017, Surabaya - Indonesia

Table 4. Duration Modelling Based on [4]

\begin{tabular}{cccccc}
\hline \multirow{2}{*}{ Number } & Activity & Distribution & Distribution Parameter (Minute) \\
& & & Low & Mid & High \\
\hline 9 & Preparation & Triangular & 10 & 13 & 18 \\
2 & Lift to Truck & Triangular & 15 & 18 & 20 \\
4 & Travel to Position & Triangular & 12 & 15 & 17 \\
6 & Placing to Position & Triangular & 15 & 18 & 20 \\
22 & Setting Girder & Triangular & 35 & 38 & 40 \\
12 & Lifting & Deterministic & & 35 & \\
14 & Lifter move to Placing Position & Triangular & 15 & 17 & 22 \\
16 & Placing Girder & Triangular & 12 & 14 & 18 \\
18 & Bracing Girder & Triangular & 13 & 17 & 20 \\
19 & Travel Back to Lifting Position & Triangular & 7 & 12 & 18 \\
11 & Travel to Yard & Triangular & 10 & 12 & 15 \\
\hline
\end{tabular}

Table 5. Cycle Productivity of Other Simulated Operations

\begin{tabular}{lccc}
\hline Operation & $\begin{array}{c}\text { Total Sim. Time } \\
\text { Unit }\end{array}$ & Cycle No. & $\begin{array}{c}\text { Productivity } \\
\text { (per time } \\
\text { unit) }\end{array}$ \\
\hline Bored Pile & 12309.3 & 500 & 0.0406197 \\
Pile Cap & 651.7 & 100 & 0.1534414 \\
Pier & 49994.7 & 170 & 0.003400 \\
Pier Head & 651.7 & 100 & 0.1534414 \\
\hline
\end{tabular}

Table 6. Cycle Productivity for Erection Girder

\begin{tabular}{ccc}
\hline Total Sim. Time Unit & Cycle No. & Productivity (per Hour) \\
\hline 15600.3 & 160 & 0.010256199 \\
\hline
\end{tabular}

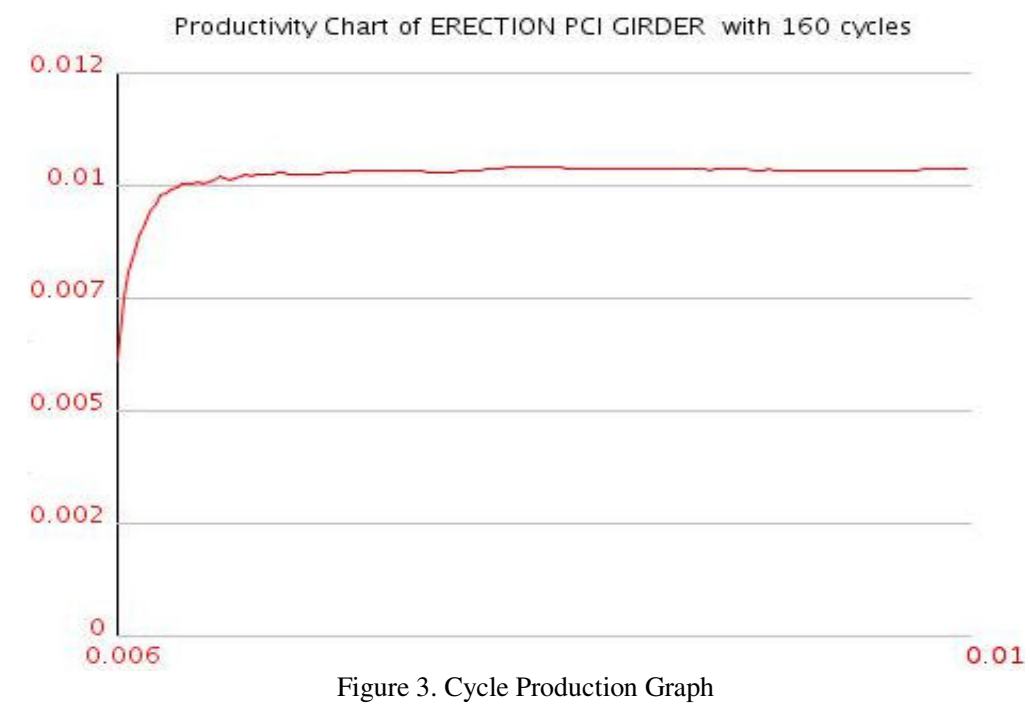


Table 7. Statistic Data for Tasks and Resources

\begin{tabular}{|c|c|c|c|c|c|c|c|c|c|}
\hline \multicolumn{10}{|c|}{ CYCLONE Passive Elements Statistics Information } \\
\hline Type & No. & Name & $\begin{array}{l}\text { Average } \\
\text { Units Idle }\end{array}$ & Max. Idle Units & Times not empty & $\%$ Idle & Total Sim Time & $\begin{array}{l}\text { Average } \\
\text { Wt Time }\end{array}$ & $\begin{array}{c}\text { Units } \\
\text { at } \\
\text { end }\end{array}$ \\
\hline QUEUE & 1 & Truck Available & 0 & 1 & 0 & 0 & 15600.3 & 0 & 0 \\
\hline QUEUE & 3 & Crane 1 & 0.8 & 1 & 12763.6 & 81.82 & 15600.3 & 78.3 & 0 \\
\hline QUEUE & 5 & Truck Ready & 0.2 & 1 & 3415.4 & 21.89 & 15600.3 & 21.2 & 0 \\
\hline QUEUE & 7 & Crane 2 & 0.8 & 1 & 12736.6 & 81.64 & 15600.3 & 78.6 & 1 \\
\hline QUEUE & 8 & Spotter 1 & 0.8 & 1 & 12736.6 & 81.64 & 15600.3 & 78.6 & 1 \\
\hline QUEUE & 10 & $\begin{array}{l}\text { Position Ready } \\
\text { for Lifting }\end{array}$ & 0.1 & 1 & 1090.2 & 6.99 & 15600.3 & 6.8 & 0 \\
\hline QUEUE & 13 & Spotter 2 & 0.6 & 1 & 9952.3 & 63.8 & 15600.3 & 61.8 & 1 \\
\hline QUEUE & 15 & $\begin{array}{l}\text { Lifter Waiting } \\
\text { for Placing }\end{array}$ & 0 & 1 & 0 & 0 & 15600.3 & 0 & 0 \\
\hline QUEUE & 17 & Erection Team & 0.9 & 1 & 13247.6 & 84.92 & 15600.3 & 82.3 & 1 \\
\hline QUEUE & 20 & $\begin{array}{c}\text { Lifter Ready to } \\
\text { Lift }\end{array}$ & 0 & 1 & 203.4 & 1.3 & 15600.3 & 1.3 & 0 \\
\hline QUEUE & 21 & Position Ready & 0 & 1 & 30.6 & 0.2 & 15600.3 & 0.2 & 0 \\
\hline
\end{tabular}

\section{RESULTS AND DISCUSSION}

Using the WebCYCLONE software, the simulation was performed until 160 cycles to achieve the steady state result (Figure 3). It was found that the operation of PC-I girder erection has productivity value of 0.010256 unit per minute or 5 units per day (Table 6). However, there are still many resources that have high percentage of idleness (Table 7). So, the sensitivity analysis should be done by changing numbers of resources that have low percentage of idleness to get the best resource allocation and the productivity as well.

Resources quantities that are changed in the sensitivity analysis are number of trucks, lifter, and position simultaneously, from 1 to 2 . The result of this sensitivity analysis is depicted in Tables 8 and 9.

In Table 9, it is shown that the initial productivity value is stable at 0.6 unit per hour. However, there are several alternative resource allocation configurations with the productivity value more than 0.6 unit per hour. The addition number of resource to each resource, i.e., two trucks, two positions, and two lifters is the best to be considered, since there is a significant increase in productivity (1.2 unit per hour) and low idleness compared to if the resources become 3 or 4; with not so much different productivity, i.e., 1.56 unit per hour.

However, the optimization of resources need to pay attention to the cost that is incurred for each addition of resources.

As depicted in Table 5, other construction operations related to the Cinapel Bridge were presented based on the simulation performed using the same CYCLONE modeling as well as the WebCYCLONE simulation system.

\section{CONCLUSION}

Based on the results of analysis and discussions of the study, it can be concluded that:

a. The productivity of the PC-I girder erection was 0.010256 unit per minute or 5 units per day. It means that total duration for erecting all 160 PC-I girders using lifter could be completed in 32 days.

b. The combination resources that will be optimal for this operation is 2 trucks, 2 lifters and 2 positions.

\section{ACKNOWLEDGEMENTS}

This study was a final project in a course, entitled Planning and Analysis Construction Operation, offered in Construction Engineering and Management Graduate Program in Civil Engineering, Faculty of Civil and Environmental Engineering, ITB, Indonesia. This study was fully supported by the Institut Teknologi Bandung. We would also like to show our gratitude to the Project Implementation Unit of the Cisumdawu Toll Road Project, the Ministry of Public Works and Human Settlement, and the contractors MCC-WIKANINDYA-WASKITA Joint Operation which provided data, insight, and expertise that greatly assisted the study. We also thank our class-mate in this course for the support during the study. 
The Third International Conference on Civil Engineering Research (ICCER)

August $1^{\text {st }}-2^{\text {nd }}$ 2017, Surabaya - Indonesia

Table 8. Sensitivity Analysis for 2 Resources

\begin{tabular}{cccr}
\hline \multicolumn{2}{c}{ Resource Information } & Productivity Information \\
\hline $\begin{array}{c}\text { \# Of Truck' At Truck } \\
\text { Available }\end{array}$ & $\begin{array}{c}\text { \# Of Lifter' At } \\
\text { Lifter Ready To } \\
\text { Lift }\end{array}$ & $\begin{array}{c}\text { \# Of Position Ready At } \\
\text { Position Ready }\end{array}$ & Productivity Per Unit Time \\
\hline 1 & 1 & 1 & 0.0103 \\
1 & 1 & 2 & 0.0103 \\
1 & 2 & 1 & 0.011 \\
1 & 2 & 2 & 0.0129 \\
2 & 1 & 1 & 0.0102 \\
2 & 1 & 2 & 0.0104 \\
2 & 2 & 1 & 0.011 \\
2 & 2 & 2 & 0.0201 \\
\hline
\end{tabular}

Table 9. Comparison of Sensitivity Analysis with Resource Additions

\begin{tabular}{ccc}
\hline $\begin{array}{c}\text { Resource } \\
\text { (Truck, Lifter and Position) }\end{array}$ & $\begin{array}{c}\text { Productivity } \\
\text { per minute }\end{array}$ & $\begin{array}{c}\text { Productivity } \\
\text { per Hour }\end{array}$ \\
\hline 1 & 0.01 & 0.6 \\
2 & 0.02 & 1.2 \\
3 & 0.026 & 1.56 \\
4 & 0.026 & 1.56 \\
\hline
\end{tabular}

Table 10. Statistic Data for Tasks and Resources for 2 Resources

\begin{tabular}{cccccccccc}
\hline Type & No. & Name & $\begin{array}{c}\text { Average Units } \\
\text { Idle }\end{array}$ & $\begin{array}{c}\text { Max. Idle } \\
\text { Units }\end{array}$ & $\begin{array}{c}\text { Times not } \\
\text { empty }\end{array}$ & $\begin{array}{c}\% \\
\text { Idle }\end{array}$ & $\begin{array}{c}\text { Total Sim } \\
\text { Time }\end{array}$ & $\begin{array}{c}\text { Average } \\
\text { Wt Time }\end{array}$ & $\begin{array}{c}\text { Units at } \\
\text { end }\end{array}$ \\
\hline QUEUE & 1 & Truck Available & 0 & 2 & 16.8 & 0.21 & 7927.5 & 0.1 & 0 \\
QUEUE & 3 & Crane 1 & 0.6 & 1 & 5054.9 & 63.76 & 7927.5 & 30.6 & 0 \\
QUEUE & 5 & Truck Ready & 0.4 & 2 & 3527 & 44.49 & 7927.5 & 21.8 & 1 \\
QUEUE & 7 & Crane 2 & 0.6 & 1 & 5045.6 & 63.65 & 7927.5 & 31 & 1 \\
QUEUE & 8 & Spotter 1 & 0.6 & 1 & 5045.6 & 63.65 & 7927.5 & 31 & 1 \\
QUEUE & 10 & Position Ready For & 0.2 & 1 & 1210.5 & 15.27 & 7927.5 & 7.5 & 0 \\
QUEUE & 13 & Lifting & Spotter 2 & 0.3 & 1 & 2301.9 & 29.04 & 7927.5 & 14.2 \\
QUEUE & 15 & Lifter Waiting For & Placing & 0 & 1 & 0 & 0 & 7927.5 & 0 \\
QUEUE & 17 & Erection Team & 0.7 & 1 & 5574.7 & 70.32 & 7927.5 & 34.6 & 0 \\
QUEUE & 20 & Lifter Ready To Lift & 0.1 & 2 & 348.3 & 4.39 & 7927.5 & 2.7 \\
QUEUE & 21 & Position Ready & 0 & 2 & 52.5 & 0.66 & 7927.5 & 0.5 \\
\hline
\end{tabular}


The Third International Conference on Civil Engineering Research (ICCER)

August $1^{\text {st }}-2^{\text {nd }}$ 2017, Surabaya - Indonesia

\section{REFERENCES}

[1] BPJT, "RJPM Toll Road 2015-2019."

[2] Halpin, D.W., Planning and Analysis of Construction Operation. John Wiley and Sons, Inc., 2002.
[3] Halpin, D.W., Senior, A.S., WebCYCLONE User's Manual. Construction Management. John Wiley and Sons, Inc., 2011

[4] Husein, W.S., Perbandingan Gantry dan Mobile Crane pada Jalan Layang Dari Segi Waktu, Metode Kerja dan Biaya, 2013. 